\title{
Dry period plane of energy: Effects on feed intake, energy balance, milk production, and composition in transition dairy cows
}

\author{
S. Mann, ${ }^{*}$ F. A. Leal Yepes, † T. R. Overton, † J. J. Wakshlag, † A. L. Lock,§ C. M. Ryan, † and D. V. Nydam*1 \\ *Department of Population Medicine and Diagnostic Sciences, and \\ †Department of Animal Science, and \\ ¥Department of Clinical Sciences, College of Veterinary Medicine, Cornell University, Ithaca, NY, 14853 \\ §Department of Animal Science, Michigan State University, East Lansing 48824
}

\begin{abstract}
The objective was to investigate the effect of different dry cow feeding strategies on the degree of ketonemia postpartum. Epidemiologic studies provide evidence of an association between elevated $\beta$-hydroxybutyrate (BHBA) concentrations in postpartum dairy cows and a decreased risk for reproductive success as well as increased risk for several diseases in early lactation, such as displacement of the abomasum and metritis. The plane of energy fed to cows in the prepartum period has been shown to influence ketogenesis and the degree of negative energy balance postpartum. Our hypothesis was that a high-fiber, controlled-energy diet (C) fed during the dry period would lead to a lower degree of hyperketonemia in the first weeks postpartum compared with either a high-energy $\operatorname{diet}(\mathrm{H})$, or a diet where an intermediate level of energy would only be fed in the close-up period (starting at $28 \mathrm{~d}$ before expected parturition), following the same controlled-energy diet in the far-off period. Hyperketonemia in this study was defined as a blood BHBA concentration of $\geq 1.2$ mmol/L. Holstein cows $(n=84)$ entering parity 2 or greater were enrolled using a randomized block design and housed in individual tiestalls. All treatment diets were fed for ad libitum intake and contained monensin. Cows received the same fresh cow ration after calving. Blood samples were obtained 3 times weekly before and after calving and analyzed for BHBA and nonesterified fatty acids (NEFA). Milk components, production, and dry matter intake were recorded and energy balance was calculated. Repeated measures ANOVA was conducted for the outcomes dry matter intake, energy balance, BHBA and NEFA concentrations, milk and energy-corrected milk yield, as well as milk composition. Predicted energy balance tended to be less negative postpartum in group $\mathrm{C}$ and cows in this group had fewer episodes of hyperketonemia compared with both
\end{abstract}

Received October 27, 2014.

Accepted January 31, 2015.

${ }^{1}$ Corresponding author: dvn2@cornell.edu the intermediate group and group $\mathrm{H}$ in the first $3 \mathrm{wk}$ after calving. Postpartum BHBA and NEFA concentrations over time were highest in group $\mathrm{H}$ and lowest in group C, whereas milk production was not affected by prepartum plane of energy. Analysis of milk fatty acid composition showed a higher yield of preformed fatty acids in group $\mathrm{H}$ compared with group $\mathrm{C}$, suggesting higher lipid mobilization for cows fed H. In this study, a 1-group, controlled-energy dry period approach decreased the degree of negative energy balance as well as the number of episodes and degree of hyperketonemia postpartum.

Key Words: dairy cow, transition period, energy, ketosis

\section{INTRODUCTION}

As dairy cows transition from the dry period into early lactation, the risk for metabolic and infectious disease is particularly high (Goff and Horst, 1997; Hammon et al., 2006; McArt et al., 2013b). After parturition, dairy cattle are faced with a sudden and marked increase of nutrient requirements to support milk production (Drackley, 1999). Improving energy balance in the postpartum period can reduce the incidence of periparturient diseases (Duffield et al., 2009) and decrease the mobilization of body reserves (Busato et al., 2002). To achieve this, it has been recommended to either maximize DMI prepartum, mitigate the drop in DMI around the time of calving, or both. Because a certain degree of decrease in DMI seems unavoidable, some authors have proposed to increase the energy content of the prepartum ration to improve production and health in early lactation (Grummer, 1995; McNamara et al., 2003; Rabelo et al., 2003). Cows fed a dry period ration with a higher energy level had a higher DMI prepartum compared with those being fed a lower energy density (Janovick and Drackley, 2010). However, research has shown that higher energy levels fed in the far-off dry period have a negative effect on peripartal metabolism (Dann et al., 2006) and lead to a greater decline in DMI prepartum (Minor et al., 1998; Olsson et 
al., 1998). Feeding a higher-energy diet prepartum can lead to an increase in body condition with subsequently more severe negative energy balance postpartum (Rukkwamsuk et al., 1999). Recent research has shown that cows with a higher prepartum body condition are at a higher risk for developing hyperketonemia (McArt et al., 2013a).

Several researchers have investigated the potential benefits of feeding a controlled-energy diet during the dry period (Grum et al., 1996; Drackley, 1999; Dann et al., 2005), and a significant improvement of fresh cow health after feeding a high-fiber, low-starch diet during the dry period has been reported in practice (Drehmann, 2000). More recent research has demonstrated that feeding a high-forage, low-energy diet prepartum improved metabolic status postpartum and reduced rates of subclinical ketosis (Janovick et al., 2011; Vickers et al., 2013). Exacerbated periparturient negative energy balance has been linked to downstream negative health events (Duffield et al., 2009; Ospina et al., 2010a; McArt et al., 2012), reduced reproductive success, and decreased production (Duffield et al., 2009; Ospina et al., 2010b,c) in several recent studies.

Current recommendations for feeding a controlledenergy diet must address the questions of how to feed dry cows to meet their requirements in an ad libitum system and how much energy should be restricted. Most of the available data are based on studies where intakes were restricted to control energy, a strategy that is not advisable on commercial dairy farms because it can lead to increased competition at the feed bunk in a freestall management system. This potentially decreases DMI in at least a part of the feed-restricted group, leading to some cows having energy intakes well below what was planned. Some uncertainty also exists about whether cows should be fed the same dry cow ration for the whole dry period or if it is preferable to change them to a higher energy plane of nutrition in the immediate prepartum period. Because we specifically wanted to isolate the effect of different energy levels and avoid differences introduced in protein availability, which might alter the plane of nutrition, diets were formulated for similar predicted amounts of MP.

Because different dry period feeding strategies have been shown to affect the level of milk production and milk composition in the immediate postpartum period, our study also aimed to describe the effects of different dry period dietary strategies on production in early lactation. Although some authors did not find a difference in ECM yield (Kunz et al., 1985; Mashek and Beede, 2001; Agenäs et al., 2003) when feeding a lower-energy diet throughout the dry period, trends for a lower fat percentage (Holter et al., 1990; McNamara et al., 2003;
Dann et al., 2006) and decreased ECM production (Olsson et al., 1998) were observed and differences were shown to be parity dependent (Rabelo et al., 2003). Several authors have shown that milk FA composition is related to the extent of energy deficit (Rukkwamsuk et al., 2000). The objectives of the current study, therefore, were to compare the effect of 3 different ad libitum dietary strategies differing in energy, starch, and fiber content, representing a range of diets that are currently used on dairy farms, including monensin, on peripartum energy balance to identify which approach would allow for a better transition of dairy cows into early lactation without affecting milk yield.

\section{MATERIALS AND METHODS}

\section{Animals, Feeding, and Management}

All procedures were evaluated and approved by the Cornell University Institutional Animal Care and Use Committee (protocol no. 2011-0016). Holstein cows (n $=84$ ) entering the second or greater lactation from the herd at the Cornell Teaching and Research Center (Harford, NY) were enrolled between September 2012 and April 2013. Exclusion criteria for enrollment were known twin pregnancy and chronic lameness, as well as having a record of a milk sample cultured positive for Staphylococcus aureus, because these animals would be managed separately. All animals were housed in individual sawdust-bedded tiestalls with feed bins and were exercised 3 times per week during the dry period. After calving, cows were milked twice daily at 0900 and $2100 \mathrm{~h}$. Cows were allocated to 1 of 3 dry period dietary treatment groups using a randomized block design with 3 treatments in 28 blocks on the day of dry off (approximately $57 \mathrm{~d}$ before expected parturition) and blocked by expected calving date. Animals were enrolled in 1 of 3 feeding groups: those that were fed a TMR formulated to meet but not greatly exceed energy requirements at predicted ad libitum intake (controlled-energy diet; C), those that received a TMR formulated to supply $150 \%$ of energy requirements (high-energy diet; $\mathbf{H}$ ), and an intermediate group that received the same TMR as group $\mathrm{C}$ for the first $28 \mathrm{~d}$ after dry off and a TMR formulated to supply $125 \%$ of energy requirements from d 28 before expected parturition until calving [intermediate diet (I), representing a 50:50 blend of both $\mathrm{C}$ and $\mathrm{H}$ diets]. Predicted DMI was anticipated to be different across the 3 treatment groups and rations were formulated using the Cornell Net Carbohydrate and Protein System software (CNCPS; Cornell University, version 6.1) accordingly, so that they were balanced for predicted MP, Lys, and Met requirements, as well as for 
a Lys-to-Met ratio of 2.9:1 All cows received the same fresh cow TMR from the onset of lactation until the end of the study period (42 DIM). Diet composition is summarized in Table 1. For all dry cow rations, predicted MP was formulated to be $1,280 \mathrm{~g} / \mathrm{d}$ and monensin was included at a target intake of $300 \mathrm{mg} / \mathrm{d}$ in all dry cow rations and at $400 \mathrm{mg} / \mathrm{d}$ in the fresh period. The straw included in all dry cow rations had a target length of no more than $5 \mathrm{~cm}$ before inclusion in the TMR mix. Dry matter content of all feed components, including the grain mix and TMR, was determined on a weekly basis by drying the sample at $60^{\circ} \mathrm{C}$ for $48 \mathrm{~h}$. Rations were adjusted each week for changes in DM content of the component. Weekly TMR samples were combined into monthly composite samples, dried, and ground in a Wiley Mill (Arthur H. Thomas, Philadelphia, PA) to pass through a 2-mm screen. All composite samples were sent for wet chemistry analysis to a commercial laboratory (Dairy One Cooperative Inc., Ithaca, NY). Samples were analyzed for DM (method 930.15; (AOAC International, 2012), CP (method 990.03; (AOAC International, 2012), starch (YSI Biochemistry Analyzer; Dairy One Cooperative, 2014), fat (method 2003.05; AOAC International, 2012), ADF (method 973.18; AOAC International, 2012), NDF (Van Soest et al., 1991), and macro- and microminerals (Sirois et al., 1994). Throughout the study, 4 composites of the commercial grain mix were analyzed accordingly to monitor the composition compared with the initial formulation. For all forages, a single composite of all monthly samples was sent for analysis. All diets were offered ad libitum, fed once daily at $0900 \mathrm{~h}$, and amounts fed were adjusted to allow for a minimum of $5 \%$ refusals.

\section{Individual Animal Sampling}

Individual feed intakes were recorded daily and calculated on a DM basis using the weekly information as described above. Blood samples $(10 \mathrm{~mL})$ were taken before feeding (between 0600 and $0730 \mathrm{~h}$ ) from the coccygeal vein or artery using evacuated tubes (Becton Dickinson Vacutainer Systems, Franklin Lakes, NJ) with 158 USP units of sodium heparin for plasma separation and a 20-gauge $\times 2.54$-cm blood collection needle, and in tubes without additive for the separation of serum. Sampling was done on the day of enrollment (57 d before expected parturition) and weekly thereafter until $21 \mathrm{~d}$ before expected parturition when sampling frequency was increased to 3 times weekly until d 21 postpartum to capture the greater variability in blood metabolites expected during the transition period (Dann et al., 2006). After d 21 postpartum, blood was again collected at weekly intervals until 42 DIM. The concentration of BHBA was determined using a handheld device (Precision Xtra meter, Abbott Diabetes Care Inc., Alameda, CA) as previously described (Iwersen et al., 2009). The calibration of all Precision Xtra meters used in our study was tested at regular intervals using a standardized solution (Medisense Glucose and Ketone Control Solutions, Abbott Diabetes Care Inc.). All blood samples were immediately placed on ice and serum and plasma were separated within $1 \mathrm{~h}$ at $2,800 \times$ $g$ for 20 min at $4^{\circ} \mathrm{C}$, snap-frozen in liquid nitrogen, and stored at $-20^{\circ} \mathrm{C}$ until analysis. Serum concentrations of NEFA were analyzed by colorimetric measurement of an enzymatic reaction [HR Series NEFA-HR (2); Wako Life Sciences, Mountain View, CA] with a microplate spectrophotometer (Epoch, Biotek, Winooski, VT). Inhouse quality control samples were run on every plate.

Animals were weighed weekly on a commercial large animal scale (Fairbanks 2200, Fairbanks Scales Inc., Kansas City, MO) and BCS, according to a 5-point scale with 0.25-point increments (according to Edmonson et al., 1989), was determined by 2 trained investigators at dry off. Calving ease on a scale from 1 to $5(1=$ normal or no assistance; $2=$ moderate assistance, provided by farm staff; $3=$ moderate assistance, but vet called as a precaution; $4=$ difficult calving, with extraction done by skilled farm staff; $5=$ very difficult calving, with maximum veterinary assistance) was recorded by the herd personnel attending each calving. Milk yield was recorded for each milking. Milk samples were obtained from 2 consecutive milkings each week. One aliquot was mixed with bronopol preservative, refrigerated at $4^{\circ} \mathrm{C}$, and analyzed for fat, true protein, TS, lactose, MUN using infrared analysis on an automated Fossomatic FT+ (Foss, Eden Prairie, MN; method 972.160; AOAC International, 2012), and SCC using optical fluorescence on a Fossomatic FC (method 972.160; AOAC International, 2012; Dairy One Cooperative Inc., Ithaca, $\mathrm{NY}$ ) within $24 \mathrm{~h}$ of collection. The second aliquot was stored at $-20^{\circ} \mathrm{C}$ without the addition of a preservative until FA composition analysis. Linear scores (LS) were calculated as LS $=\left\{\log _{2}[(\mathrm{SCC} / 100,000)+3]\right\}$.

Hyperketonemia was defined as BHBA $\geq 1.2 \mathrm{mmol} / \mathrm{L}$ (McArt et al., 2013a). Cows were considered to have clinical ketosis if $\mathrm{BHBA} \geq 2.5 \mathrm{mmol} / \mathrm{L}$ and were treated with $250 \mathrm{~mL}$ of a $50 \%$ dextrose solution (Dextrose $50 \%$ inj, i.v., VetOne, Boise, ID) on 2 consecutive days as well as $300 \mathrm{~mL}$ (approximately $310 \mathrm{~g}$ ) of propylene glycol orally for 5 consecutive days starting on the day of diagnosis. Subsequent episodes of clinical ketosis after this initial treatment were treated with another 5-d course of oral propylene glycol alone. This was repeated until BHBA concentrations were determined to be $<2.5$ $\mathrm{mmol} / \mathrm{L}$. Health events, such as displacement of the 
Table 1. Ingredient composition of diets (\% of DM)

\begin{tabular}{|c|c|c|c|c|}
\hline \multirow[b]{2}{*}{ Ingredient } & \multicolumn{3}{|c|}{ Treatment $^{1}$} & \multirow[b]{2}{*}{ Fresh } \\
\hline & Controlled & Intermediate & High & \\
\hline Corn silage & 28.5 & 42.2 & 55.9 & 44.2 \\
\hline Wheat straw & 35.6 & 24.0 & 12.4 & - \\
\hline Hay crop silage & - & - & - & 10.7 \\
\hline Grass hay & - & - & - & 2.7 \\
\hline Amino Plus ${ }^{2}$ & 10.5 & 6.0 & 1.5 & 4.5 \\
\hline Canola meal, solvent extracted & 6.8 & 7.9 & 8.9 & 9.8 \\
\hline Distillers grain, ethanol & 4.5 & 3.0 & 1.6 & 7.2 \\
\hline Citrus pulp & 3.7 & 4.4 & 5.1 & - \\
\hline Corn grain, finely ground & 2.6 & 3.6 & 4.6 & 4.7 \\
\hline Soybean hulls & 2.4 & 3.7 & 5.0 & 6.0 \\
\hline Corn germ meal & - & - & - & 3.8 \\
\hline Chocolate dairy mix & - & - & - & 1.0 \\
\hline Blood meal & 0.53 & 0.45 & 0.38 & 0.84 \\
\hline Energy booster ${ }^{3}$ & - & - & - & 0.78 \\
\hline Dextrose & - & - & - & 0.73 \\
\hline Molasses & - & - & - & 0.93 \\
\hline Soy Chlor ${ }^{4}$ & 1.71 & 1.26 & 0.82 & - \\
\hline Calcium carbonate & 1.05 & 1.28 & 1.53 & 0.93 \\
\hline Calcium sulfate & 0.64 & 0.45 & 0.25 & 0.00 \\
\hline Magnesium sulfate $9.9 \%$ & 0.54 & 0.79 & 1.05 & - \\
\hline Salt & 0.31 & 0.29 & 0.27 & 0.50 \\
\hline Mono-dicalcium phosphate & 0.21 & 0.27 & 0.34 & - \\
\hline Magnesium oxide $56 \%$ & 0.17 & 0.17 & 0.15 & 0.15 \\
\hline Alimet $^{5}$ & 0.07 & 0.07 & 0.06 & 0.04 \\
\hline Dairy $\mathrm{ADE}^{6}$ & 0.05 & 0.05 & 0.05 & 0.03 \\
\hline Selenium $0.06 \%$ & 0.05 & 0.05 & 0.05 & 0.05 \\
\hline Urea & - & - & - & 0.06 \\
\hline 1100 Dairy $\mathrm{TM}^{7}$ & 0.03 & 0.03 & 0.03 & 0.03 \\
\hline Rumensin $90^{8}$ & 0.01 & 0.01 & 0.01 & 0.01 \\
\hline Sodium bicarbonate & — & — & - & 0.01 \\
\hline Vitamin E premix $^{9}$ & 0.005 & 0.004 & 0.003 & - \\
\hline Zinc sulfate & 0.003 & 0.002 & 0.002 & - \\
\hline Copper sulfate & 0.0007 & 0.0008 & 0.0009 & 0.0001 \\
\hline
\end{tabular}

${ }^{1}$ Treatments: controlled-energy prepartum diet, fed for ad libitum intake to control intake to $100 \%$ of energy requirements; intermediate-energy prepartum diet, fed for ad libitum intake to control intake to 100\% of energy requirements from 57 to $29 \mathrm{~d}$ before expected parturition and approximately $125 \%$ of energy requirements from 28 d before expected parturition until calving; high-energy prepartum diet, fed for ad libitum intake to achieve energy intake at approximately $150 \%$ of requirements.

${ }^{2}$ Soybean product; Ag Processing Inc., Omaha, NE.

${ }^{3}$ Prilled FA; Milk Specialties Global, Eden Prairie, MN.

${ }^{4}$ Anionic feed supplement; West Central, Ralston, IA.

${ }^{5}$ 2-Hydroxy-4-methyl-thio-butanoic acid, Novus International, St. Charles, MO.

${ }^{6}$ Contained 30,464 IU $/ \mathrm{kg}$ of vitamin A, 5,862 IU/kg of vitamin D, and 93,784 IU $/ \mathrm{kg}$ of vitamin E (Cargill Animal Nutrition business, Minneapolis, MN).

${ }^{7}$ Contained $30,317 \mathrm{mg} / \mathrm{kg}$ of Cu, 136,466 mg/kg of $\mathrm{Mn}, 3,393 \mathrm{mg} / \mathrm{kg}$ of Co, 3,040 mg/kg of I, and 153,916 mg/ $\mathrm{kg}$ of Zn (Cargill Animal Nutrition business).

${ }^{8}$ Contained $200 \mathrm{~g}$ of monensin/kg; Elanco Animal Health, Greenfield, IN.

${ }^{9}$ Contained 499,400 IU $/ \mathrm{kg}$ of vitamin E.

abomasum, mastitis, and ketosis, were recorded daily for all animals throughout the study period. Retained placenta was defined as the failure to pass fetal membranes by $24 \mathrm{~h}$ after calving.

On $\mathrm{d}-28 \pm 1$ and $-10 \pm 1$ relative to expected calving, as well as on $4 \pm 1$ and $21 \pm 1$ DIM, all cows on study had subcutaneous fat and muscle biopsies taken and a glucose tolerance test was performed (data not presented) with $0.25 \mathrm{~g} / \mathrm{kg}$ of dextrose (Dextrose $50 \%$ inj., VetOne) administered intravenously. Additionally, animals received $2.2 \mathrm{mg} / \mathrm{kg}$ of flunixin meglumine (Prevail, VetOne) intravenously for pain mitigation following biopsy.

\section{Calculations and Estimations}

Rations were formulated using CNCPS. The chemical composition of all forages, as determined by Dairy One, 
and the composition of the grain as formulated were entered into CNCPS to estimate the energy content of all the diets. The energy density of the diets was also estimated separately according to the NRC software (NRC, 2012). Energy balance was estimated in CNCPS based on weekly averages for each cow's BW and DMI and either carried calf for dry period estimates or milk yield as well as percent milk fat, protein, and lactose for the postpartum period. Energy balance was expressed as a percentage of requirements. The results of energy density estimates obtained from the NRC software were also used to calculate energy balance for the dry period, as well as for early lactation according to NRC (2001), as previously described by Dann et al. (2006). Predicted MP amount for average intakes in all prepartum treatment groups was estimated with CNCPS. Weight gain comparison among the groups was calculated as the weight at $45 \mathrm{~d}$ after dry off minus the weight at dry off.

Energy-corrected milk yield was calculated for 3.5\% fat and 3.0\% protein as follows: ECM $(\mathrm{kg})=\{[(0.0929$ $\times$ fat $\%)+(0.0563 \times$ true protein $\%)+0.192] \times$ milk $(\mathrm{kg}) / 0.68605\}$. Fat and protein concentrations for each of the 2 consecutive milkings within a sample day were summed and the average entered into the formula. Milk samples from the second and fourth week after calving were analyzed for FA composition as previously described (Lock et al., 2013). In brief, morning and afternoon milk samples from each sampling period were composited based on milk fat yield. Following extraction and methylation of lipids, gas-liquid chromatography was used to determine the composition of FAME. Using the molecular weight of each FA, milk fat yield, and FA concentration, yields of individual FA (g/d) were calculated (Piantoni et al., 2013).

\section{Analytical Approach}

The primary outcome of interest in the study was the difference in BHBA blood concentrations among the treatment groups. The sample size of 28 animals per group was based on identifying a biological difference in BHBA concentration between the $\mathrm{C}$ and $\mathrm{H}$ groups of $0.4 \mathrm{mmol} / \mathrm{L}$ with a SD of 0.4 , confidence level of $95 \%$, and power of $95 \%$. To minimize potentially unmeasured bias associated with environmental factors on a dairy farm that change over time, animals were blocked in groups of 3 . Allocation within the block was performed following the sequence of a random number generator (Research Randomizer v.4.0, Urbaniak, 2012). Secondary outcomes included differences in DMI, NEFA concentrations, BW, and milk production and composition.

Chi-squared tests were generated using PROC FREQ of SAS (SAS 9.3, SAS Institute Inc., Cary, NC) for differences in calving scores, parity, calf sex, episodes of BHBA $\geq 1.2 \mathrm{mmol} / \mathrm{L}$, as well as treatment episodes for clinical ketosis. One-way ANOVA were carried out with PROC ANOVA for differences in days dry, BCS, and BW measurements and FA composition. Repeated measures ANOVA was performed for the outcomes DMI, energy balance, BHBA and NEFA concentrations, milk and ECM yield, percentage of milk fat, protein, lactose, and TS, as well as MUN concentration and linear scores using PROC MIXED in SAS. Five covariance structures were tested for each variable analyzed (simple, compound symmetry, autoregressive order 1, Toeplitz, and unstructured). The covariance structure with the smallest Akaike's information criterion was chosen. Fixed effects were treatment group and parity with the REPEATED statement for the time variable. Interaction terms were removed from the model unless the $P$-value was $\leq 0.05$; the interaction of treatment group and time was forced into every model. Data were analyzed separately for pre- and postpartum. For every model, the effect of enrollment block was tested. When results of the ANOVA analysis yielded a $P$-value of $\leq 0.05$, Tukey's post hoc test was used for comparison of means across all groups to control experiment-wise error rate. Normality of residuals was tested after each model fit.

\section{RESULTS}

\section{Description of Study Population}

Two cows had to be replaced 2 wk after enrollment because 1 animal aborted and 1 was severely lame. Twenty-eight cows in each group completed the dry period. One cow in group $\mathrm{C}$ had to be euthanized in the third week postpartum due to severe toxic mastitis following a teat laceration, 2 animals in group I were sold, 1 in the fourth and 1 in the fifth week postpartum because of a presumed perforating abomasal ulcer and severe mastitis, respectively.

Descriptive statistics are provided in Table 2. Cows were dry for an average of $55.5 \mathrm{~d}$ (C: $56.5 \mathrm{~d}$, I: 55.0 $\mathrm{d}, \mathrm{H}: 55.2 \mathrm{~d} ; P=0.4)$. One cow in the $\mathrm{C}$ group was pregnant to a later breeding date and was dry for 99 d; however, she was still included in the analysis unless indicated. Weight gain in the dry period was $72.1 \pm$ $18.7,71.0 \pm 19.2$, and $90.4 \pm 23.5 \mathrm{~kg}$ in the $\mathrm{C}$, I, and $\mathrm{H}$ groups, respectively $(P=0.0008)$. Weight loss from 4 to 21 DIM was $24.8 \pm 22.1,40.6 \pm 32.9$, and $37.8 \pm$ $31.8 \mathrm{~kg}$ in the $\mathrm{C}, \mathrm{I}$, and $\mathrm{H}$ groups, respectively $(P=$ 0.11 ). Weight loss from 4 to 42 DIM was $30.7 \pm 26.5$, $45.5 \pm 34.8$, and $40.3 \pm 32.2 \mathrm{~kg}$ in the $\mathrm{C}$, I, and $\mathrm{H}$ groups, respectively $(P=0.22)$.

Calving scores in the $\mathrm{C}$, I, and $\mathrm{H}$ groups, respectively were distributed as follows: 20/28 (71.4\%), 
Table 2. Descriptive statistics of all animals by treatment group; results presented as mean value \pm SD

\begin{tabular}{|c|c|c|c|c|c|}
\hline \multirow[b]{2}{*}{ Measurement } & \multicolumn{3}{|c|}{ Treatment $^{1}$} & \multirow[b]{2}{*}{ Overall } & \multirow[b]{2}{*}{$P$} \\
\hline & Controlled & Intermediate & High & & \\
\hline \multicolumn{6}{|l|}{ Entering parity } \\
\hline 2 & 15 & 16 & 20 & $51(60.71 \%)$ & 0.34 \\
\hline 3 & 11 & 11 & 5 & $27(32.14 \%)$ & \\
\hline 4 & 1 & 0 & 3 & $4(4.76 \%)$ & \\
\hline 5 & 1 & 1 & 0 & $2(2.38 \%)$ & \\
\hline $\mathrm{BW}, \mathrm{kg}$ & $673 \pm 73$ & $684 \pm 64$ & $660 \pm 65$ & $672 \pm 67$ & 0.43 \\
\hline $\mathrm{BCS}$ & $3.1 \pm 0.3$ & $3.2 \pm 0.3$ & $3.1 \pm 0.2$ & $3.1 \pm 0.3$ & 0.24 \\
\hline Dry period, ${ }^{2} \mathrm{~d}$ & $56.5 \pm 3.1$ & $55.0 \pm 5.4$ & $55.2 \pm 4.3$ & $56.1 \pm 6.4$ & 0.40 \\
\hline \multicolumn{6}{|c|}{$\begin{array}{l}{ }^{1} \text { Treatments: controlled-energy prepartum diet, fed for ad libitum intake to control intake to } 100 \% \text { of ener } \\
\text { requirements; intermediate-energy prepartum diet, fed for ad libitum intake to control intake to } 100 \% \text { of ener } \\
\text { requirements from } 57 \text { to } 29 \text { d before expected parturition and approximately } 125 \% \text { of energy requirements fro } \\
28 \text { d before expected parturition until calving; high-energy prepartum diet, fed for ad libitum intake to achie } \\
\text { energy intake at approximately } 150 \% \text { of requirements. }\end{array}$} \\
\hline
\end{tabular}

$16 / 28(57.1 \%)$, and $22 / 28(78.6 \%)$ animals scored 1 ; $6 / 28(21.4 \%), 8 / 28(28.6 \%)$, and $5 / 28(17.9 \%)$ animals scored $2 ; 2 / 28(7.1 \%) ,3 / 28(10.7 \%)$, and $1 / 28(3.6 \%)$ animals scored 3 ; and 1 animal in group I 1/28 (3.6\%) had a score of $4(P=0.60)$. One animal in group I had twins.

\section{Description of Diets and Intakes}

The analyzed composition of pre- and postpartum diets is presented in Table 3. Prepartum DMI was different between groups with the lowest intakes $(14.2 \pm 0.3$ $\mathrm{kg}$ ) in group $\mathrm{C}$ and the highest intake in group $\mathrm{H}$ (16.4 $\pm 0.3 \mathrm{~kg}$; Figure 1, Table 4). Postpartum DMI was not different among groups $(22.3 \pm 0.6,22.38 \pm 0.6$, and $22.4 \pm 0.6 \mathrm{~kg}$ for the $\mathrm{C}$, I, and $\mathrm{H}$ groups, respectively; $P$ $=0.99 ;$ Figure 1, Table 4). Energy balance predictions using the CNCPS model are listed in Table 4. Predictions obtained from the NRC model are shown in Figure 2 to contrast estimates from the CNCPS model for both pre- and postpartum time points. The NRC model yielded the highest estimates of prepartum energy balance (C: $140.7 \pm 3.1 \%$, I: $156.6 \pm 3.1 \%$, and $\mathrm{H}: 176.8$ $\pm 3.1 \%$, respectively), whereas the CNCPS calculations yielded overall lower results (C: $111.9 \pm 2.2 \%$, I: 125.8 $\pm 2.2 \%$, and $\mathrm{H}: 152.5 \pm 2.3 \%$. The predicted energy density of the diets in the CNCPS model were 1.98, $2.12,2.23$, and $2.42 \mathrm{Mcal}$ of ME/kg of DM for the C, I, $\mathrm{H}$, and fresh cow TMR diets, respectively, whereas the NRC model predicted higher energy densities across all groups $(2.31,2.38,2.45$, and $2.55 \mathrm{Mcal}$ of $\mathrm{ME} / \mathrm{kg}$ of $\mathrm{DM})$. Based on average DMI, predicted MP was on average $1,490,1,520$, and $1,520 \mathrm{~g} / \mathrm{d}$ in the $\mathrm{C}$, I, and $\mathrm{H}$ groups, respectively, thus supplying 124, 123, and $118 \%$ of the MP requirements in the treatment groups as estimated by CNCPS.

\section{Milk Production and Composition}

Milk production and ECM are presented in Table 5. Milk and ECM production was not different in the 3 treatment groups. Results for milk components are summarized in Table 5. Milk fat was the component with the most notable difference among the 3 groups and was $3.96 \pm 0.09,4.12 \pm 0.09$, and $4.24 \pm 0.09 \%$ in the $\mathrm{C}$, I, and $\mathrm{H}$ groups, respectively $(P=0.10)$. Milk FA yield and concentration for wk 2 and 4 postpartum are summarized in Table 6, respectively. The yield of preformed FA in the $\mathrm{H}$ group was $117 \mathrm{~g}$ higher in wk 2 and $76 \mathrm{~g}$ higher in wk 4 compared with the $\mathrm{C}$ group, whereas no difference was found in the yield of de novo FA (Table 6). The difference in preformed FA was driven by a higher yield of both C18:0 and cis-9 C18:1. Cows fed a high-energy diet during the dry period also had higher concentrations of C18:0 in milk fat (Table 6). Neither yield nor concentration of mixed source FA (C16:0 and cis-9 C16:1) were different among treatment groups.

\section{Energy Metabolites and Health Events}

The BHBA concentrations in the 3 groups were different over time (Figure 3). Compared with group $\mathrm{H}$, cows in group $\mathrm{C}$ had overall lower BHBA levels in the last 2 wk prepartum $(0.29 \pm 0.01$ vs. $0.34 \pm 0.01$ $\mathrm{mmol} / \mathrm{L})$, as well as in the first $3 \mathrm{wk}$ postpartum (0.61 \pm 0.06 vs. $0.84 \pm 0.07 \mathrm{mmol} / \mathrm{L}$; Table 7 ). Of all BHBA tests within the first 21 DIM, 13, 32, and 31 episodes of hyperketonemia were recorded in groups C, I, and $\mathrm{H}$, respectively $(P=0.007)$. The median time to first positive test was $7 \mathrm{~d}$. No cows were treated for clinical ketosis in group C, whereas 4 cows in group I and 5 cows in group $\mathrm{H}$ received treatment $(P=0.07)$. 
Table 3. Analyzed composition of diets

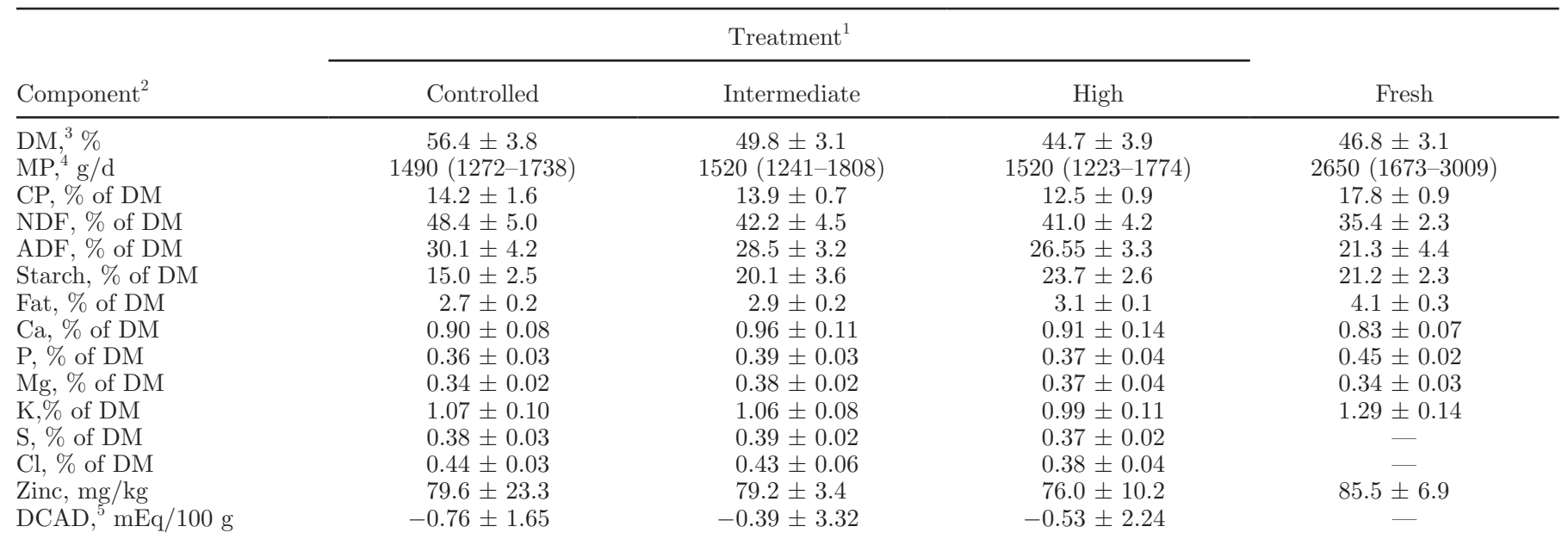

${ }^{1}$ Treatments: controlled-energy prepartum diet, fed for ad libitum intake to control intake to $100 \%$ of energy requirements; intermediate-energy prepartum diet, fed for ad libitum intake to control intake to $100 \%$ of energy requirements from 57 to $29 \mathrm{~d}$ before expected parturition and approximately $125 \%$ of energy requirements from $28 \mathrm{~d}$ before expected parturition until calving; high-energy prepartum diet, fed for ad libitum intake to achieve energy intake at approximately $150 \%$ of requirements.

${ }^{2}$ Chemical composition is presented as average of 11 monthly composites $\pm \mathrm{SD}$ (except DM).

${ }^{3}$ Average $\pm \mathrm{SD}$ of 36 weekly DM measurements.

${ }^{4}$ Prediction of MP supply for average DMI (range given for \pm SD in DMI) in each treatment group for the last 7 wk before calving and for overall average intakes postpartum (CNCPS v.6.1).

${ }^{5}$ Calculated as $[(\mathrm{Na}+\mathrm{K})-(\mathrm{Cl}+\mathrm{S})]$. Percent sodium, potassium, chloride, and sulfur were multiplied by 434.98, 255.74, 282.06 , and 623.75 to convert to $\mathrm{mEq} / \mathrm{kg}$, respectively.
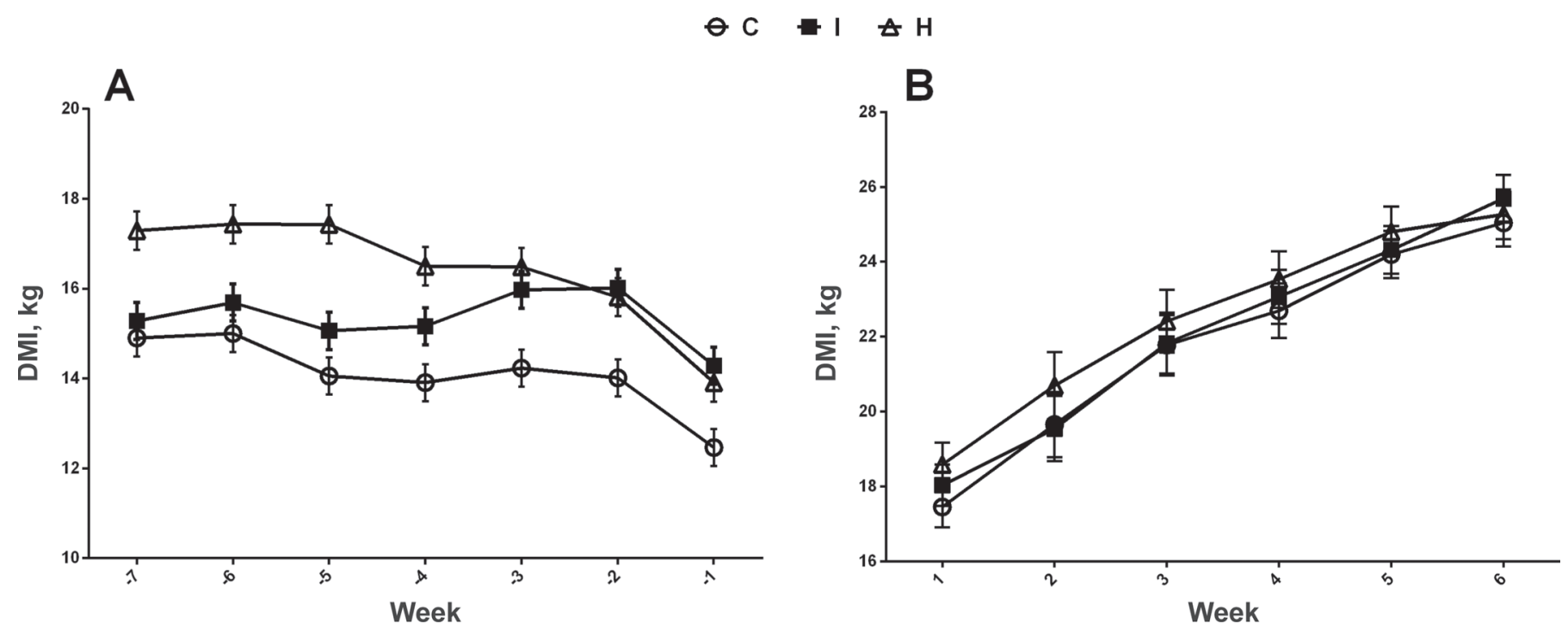

Figure 1. Dry matter intake (kg) wk 7 to 1 prepartum (A) and wk 1 to 6 postpartum (B) for the 3 treatment groups. C = controlled-energy prepartum diet, fed for ad libitum intake to control intake to $100 \%$ of energy requirements; I = intermediate-energy prepartum diet, fed for ad libitum intake to control intake to $100 \%$ of energy requirements from 57 to $29 \mathrm{~d}$ before expected parturition and approximately $125 \%$ of energy requirements from $28 \mathrm{~d}$ before expected parturition until calving; $\mathrm{H}=$ high-energy prepartum diet, fed for ad libitum intake to achieve energy intake at approximately $150 \%$ of requirements. At parturition, all cows were fed the same lactation diet. Data are presented as LSM \pm SE. Prepartum: treatment, $P<0.001$; time $P<0.001$; parity, $P<0.001$; treatment $\times$ time, $P=0.03$; time $\times$ parity $P<0.001$. Postpartum: treatment, $P=0.99$; time, $P<0.001$; parity, $P=0.37$; treatment $\times$ time, $P=0.75$; treatment $\times$ parity, $P=0.04$. Parity was categorized into parity 2 or $\geq 3$. Interactions of main effects treatment, time, and parity were removed if $P \geq 0.05$, except treatment $\times$ time, which was forced in the model. 
Table 4. Repeated measures LSM for DMI as well as energy balance estimates obtained with the Cornell Net Carbohydrate and Protein model (CNCPS version 6.1)

\begin{tabular}{|c|c|c|c|c|c|c|c|c|c|c|c|}
\hline \multirow[b]{2}{*}{ Variable } & \multicolumn{3}{|c|}{ Treatment $^{1}( \pm \mathrm{SE})$} & \multicolumn{2}{|c|}{ Parity $( \pm \mathrm{SE})$} & \multicolumn{6}{|c|}{$P$-value for fixed effects ${ }^{2}$} \\
\hline & $\mathrm{C}$ & I & $\mathrm{H}$ & 2 & $\geq 3$ & $\mathrm{~T}$ & Time & $\mathrm{P}$ & $\mathrm{T} \times$ Time & $\mathrm{T} \times \mathrm{P}$ & Time $\times \mathrm{P}$ \\
\hline \multicolumn{12}{|l|}{ EBAL, ${ }^{3} \%$ prepartum } \\
\hline $\begin{array}{l}\text { wk }-r \text { to }-1 \\
\text { wk }-7\end{array}$ & $\begin{array}{l}112 \pm 2^{a} \\
126 \pm 3\end{array}$ & $\begin{array}{l}126 \pm 2 \\
127 \pm 3\end{array}$ & $\begin{array}{l}153 \pm 2 \\
171 \pm 3\end{array}$ & $\begin{array}{l}130 \pm 2 \\
139 \pm 2\end{array}$ & $\begin{array}{l}130 \pm 2 \\
144 \pm 3\end{array}$ & $<0.001$ & $<0.001$ & 0.85 & $<0.001$ & - & 0.005 \\
\hline wk -4 & $115 \pm 4$ & $129 \pm 4$ & $157 \pm 4$ & $132 \pm 2$ & $135 \pm 3$ & & & & & & \\
\hline wk -1 & $91 \pm 3$ & $113 \pm 3$ & $121 \pm 3$ & $113 \pm 2$ & $103 \pm 3$ & & & & & & \\
\hline \multicolumn{12}{|l|}{ EBAL,$~^{3} \%$ postpartum } \\
\hline wk 1 to 6 & $77 \pm 1.5$ & $74 \pm 1.6$ & $72 \pm 1.5$ & $77 \pm 1.1$ & $72 \pm 1.4$ & 0.09 & $<0.001$ & 0.02 & 0.75 & - & - \\
\hline wk 2 & $69 \pm 2.5$ & $65 \pm 2.5$ & $64 \pm 2.6$ & & & & & & & & \\
\hline wk 4 & $78 \pm 1.8$ & $76 \pm 1.8$ & $74 \pm 1.8$ & & & & & & & & \\
\hline wk 6 & $87 \pm 1.6$ & $85 \pm 1.6$ & $82 \pm 1.6$ & & & & & & & & \\
\hline \multicolumn{12}{|l|}{ DMI, $\mathrm{kg}$ prepartum } \\
\hline wk -7 to -1 & $14.2 \pm 0.3^{\mathrm{a}}$ & $15.3 \pm 0.3^{\mathrm{b}}$ & $16.4 \pm 0.3^{\mathrm{c}}$ & $14.7 \pm 0.2$ & $15.9 \pm 0.3$ & $<0.001$ & $<0.001$ & $<0.001$ & 0.03 & - & $<0.001$ \\
\hline wk -7 & $14.9 \pm 0.4$ & $15.3 \pm 0.4$ & $17.3 \pm 0.4$ & $14.9 \pm 0.3$ & $16.7 \pm 0.4$ & & & & & & \\
\hline wk -4 & $13.9 \pm 0.4$ & $15.2 \pm 0.4$ & $16.5 \pm 0.4$ & $14.3 \pm 0.3$ & $16.1 \pm 0.4$ & & & & & & \\
\hline wk -1 & $12.5 \pm 0.4$ & $14.3 \pm 0.4$ & $13.9 \pm 0.4$ & $14.0 \pm 0.3$ & $13.1 \pm 0.4$ & & & & & & \\
\hline \multicolumn{12}{|l|}{ DMI, kg postpartum } \\
\hline wk 1 to 6 & $22.3 \pm 0.6$ & $22.4 \pm 0.6$ & $22.4 \pm 0.6$ & $22.1 \pm 0.4$ & $22.6 \pm 0.5$ & 0.99 & $<0.001$ & 0.37 & 0.75 & 0.04 & - \\
\hline wk 2 & $19.7 \pm 0.9$ & $19.5 \pm 0.9$ & $20.7 \pm 0.9$ & & & & & & & & \\
\hline wk 4 & $22.7 \pm 0.7$ & $23.1 \pm 0.7$ & $23.5 \pm 0.8$ & & & & & & & & \\
\hline wk 6 & $25.0 \pm 0.6$ & $25.7 \pm 0.6$ & $25.3 \pm 0.7$ & & & & & & & & \\
\hline $\mathrm{C}$ & & & & $22.0 \pm 0.8$ & $21.7 \pm 0.8$ & & & & & & \\
\hline I & & & & $22.7 \pm 0.7$ & $21.5 \pm 0.8$ & & & & & & \\
\hline $\mathrm{H}$ & & & & $22.0 \pm 0.8$ & $23.8 \pm 1.0$ & & & & & & \\
\hline
\end{tabular}

Main effects of treatment in the same row with different superscripts differ $(P \leq 0.05)$.

${ }^{1}$ Treatments: $\mathrm{C}=$ controlled-energy prepartum diet, fed for ad libitum intake to control intake to $100 \%$ of energy requirements; I = intermediate-energy prepartum diet, fed for

Q 을 expected parturition until calving; $\mathrm{H}=$ high-energy prepartum diet, fed for ad libitum intake to achieve energy intake at approximately $150 \%$ of requirements.

ㄱ. ${ }^{2}$ Fixed effects are treatment group $(\mathrm{T})$, parity $(\mathrm{P} ; 2$ or $\geq 3$ ), time, and 2 -way interactions; interactions with $P \geq 0.05$ were excluded from the model except for treatment group $\times$ 芦. time.

C) ${ }^{3} \mathrm{EBAL}=$ energy balance in percent of requirements (CNCPS v. 6.1). 

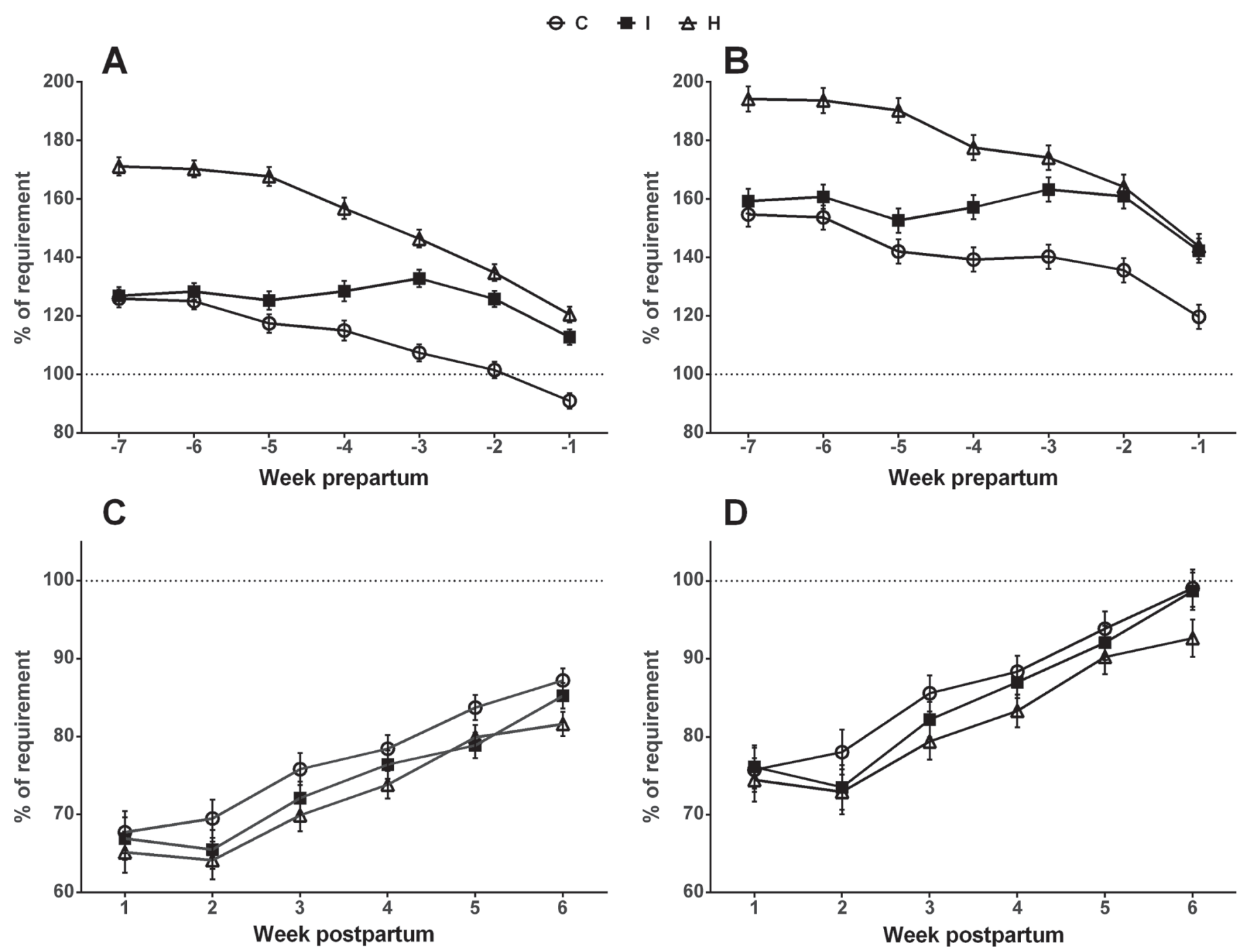

Figure 2. Comparison of energy balance (percent of requirements) estimates. Estimations of prepartum (wk 7 to 1 prepartum) energy balance with the Cornell Net Carbohydrate and Protein System (CNCPS v.6.1; A) or according to NRC (2001; B) and postpartum (wk 1 to 6 postpartum) with CNCPS v. 6.1 (C) and NRC (D) models. C = controlled-energy prepartum diet, fed for ad libitum intake to control intake to $100 \%$ of energy requirements; I = intermediate-energy prepartum diet, fed for ad libitum intake to control intake to $100 \%$ of energy requirements from 57 to 29 d before expected parturition and approximately $125 \%$ of energy requirements from 28 d before expected parturition until calving; $\mathrm{H}=$ high-energy prepartum diet, fed for ad libitum intake to achieve energy intake at approximately $150 \%$ of requirements. At parturition, all cows were fed the same lactation diet. Data are presented as LSM \pm SE. (A) Prepartum CNCPS: treatment, $P<0.001$; time, $P<0.001$; parity, $P=0.85$; treatment $\times$ time, $P<0.001$; time $\times$ parity, $P=0.005$ (B) Prepartum NRC: treatment, $P<0.001$; time, $P<0.001 ;$ parity, $P=$ 0.53; treatment $\times$ time, $P<0.001$; time $\times$ parity, $P=0.001($ C) Postpartum CNCPS: treatment, $P<0.09$; time, $P<0.001$; parity, $P=0.02$; treatment $\times$ time, $P<0.75$ (D) Postpartum NRC: treatment, $P<0.20$; time, $P<0.001$; parity, $P=0.06$; treatment $\times$ time, $P<0.86$. Parity was categorized into entering parity 2 or $\geq 3$. Interactions of main effects treatment, time, and parity removed if $P \geq 0.05$, except treatment $\times$ time, which was forced in the model.

Intra- and interassay coefficients of variation for NEFA measurements determined from 15 assays were 3.1 and $8.2 \%$, respectively. Concentrations of NEFA were also different among the dietary treatment groups over time (Figure 3 ). In the prepartum period, animals in group $\mathrm{C}$ had higher concentrations compared with both group I and $\mathrm{H}(\mathrm{C}: 237 \pm 12 \mu \mathrm{Eq} / \mathrm{L}, \mathrm{I}: 180 \pm$ $13 \mu \mathrm{Eq} / \mathrm{L}, \mathrm{H}: 175 \pm 12 \mu \mathrm{Eq} / \mathrm{L})$. Postpartum NEFA concentrations were lower in group $\mathrm{C}$ and I compared with group H $(\mathrm{C}: 659 \pm 36 \mu \mathrm{Eq} / \mathrm{L}, \mathrm{I}: 665 \pm 37 \mu \mathrm{Eq} / \mathrm{L}$, H: $796 \pm 40 \mu \mathrm{Eq} / \mathrm{L}$; Table 7).

One animal in group $\mathrm{C}$ and 1 animal in group I, as well as 2 animals in group $\mathrm{H}$, suffered from left displacement of the abomasum. All cases were corrected via the roll and toggle method. One, 3 , and 4 cows in groups $\mathrm{C}$, $\mathrm{I}$, and $\mathrm{H}$ developed clinical mastitis, respectively. Six, 
Table 5. Repeated measures ANOVA LSM for milk and ECM yield as well as milk composition

\begin{tabular}{|c|c|c|c|c|c|c|c|c|c|}
\hline Variable & \multicolumn{3}{|c|}{ Treatment $^{1}( \pm \mathrm{SE})$} & \multicolumn{2}{|c|}{ Parity $( \pm \mathrm{SE})$} & \multicolumn{4}{|c|}{$P$-value for fixed effects ${ }^{2}$} \\
\hline \multicolumn{10}{|l|}{ Milk, kg } \\
\hline $\begin{array}{l}\text { wk } 1 \text { to } 6 \\
\text { wk } 2\end{array}$ & $\begin{array}{l}43.8 \pm 1.2 \\
40.9 \pm 1.4\end{array}$ & $\begin{array}{l}43.6 \pm 1.2 \\
40.9 \pm 1.4\end{array}$ & $\begin{array}{l}43.9 \pm 1.2 \\
41.9 \pm 1.4\end{array}$ & $43.5 \pm 0.9$ & $44.0 \pm 1.1$ & 0.98 & $<0.01$ & 0.73 & 0.31 \\
\hline wk 4 & $48.1 \pm 1.4$ & $46.5 \pm 1.4$ & $46.7 \pm 1.4$ & & & & & & \\
\hline wk 6 & $49.4 \pm 1.3$ & $48.5 \pm 1.3$ & $49.0 \pm 1.3$ & & & & & & \\
\hline wk 2 & $47.0 \pm 1.5$ & $47.1 \pm 1.5$ & $49.8 \pm 1.5$ & & & & & & \\
\hline wk 4 & $47.9 \pm 1.5$ & $48.3 \pm 1.5$ & $49.6 \pm 1.5$ & & & & & & \\
\hline wk 6 & $46.4 \pm 1.5$ & $47.4 \pm 1.5$ & $48.1 \pm 1.5$ & & & & & & \\
\hline \multicolumn{10}{|l|}{ Fat, \% } \\
\hline wk 1 to 6 & $3.96 \pm 0.09$ & $4.12 \pm 0.09$ & $4.24 \pm 0.09$ & $3.98 \pm 0.07$ & $4.24 \pm 0.08$ & 0.10 & $<0.01$ & 0.02 & 0.97 \\
\hline wk 2 & $4.44 \pm 0.16$ & $4.63 \pm 0.15$ & $4.76 \pm 0.15$ & & & & & & \\
\hline wk 4 & $3.65 \pm 0.12$ & $3.93 \pm 0.12$ & $4.11 \pm 0.12$ & & & & & & \\
\hline \multirow{2}{*}{\multicolumn{10}{|c|}{ Lactose $\%$}} \\
\hline & & & & & & & & & \\
\hline wk 1 to 6 & $4.68 \pm 0.04$ & $4.72 \pm 0.04$ & $4.75 \pm 0.04$ & $4.77 \pm 0.03$ & $4.67 \pm 0.03$ & 0.53 & $<0.01$ & 0.004 & 0.88 \\
\hline wk 2 & $4.63 \pm 0.08$ & $4.74 \pm 0.08$ & $4.76 \pm 0.08$ & & & & & & \\
\hline wk 4 & $4.72 \pm 0.05$ & $4.79 \pm 0.05$ & $4.83 \pm 0.05$ & & & & & & \\
\hline \multirow{2}{*}{\multicolumn{10}{|c|}{ Linear score ${ }^{3}$}} \\
\hline & & & & & & & & & \\
\hline wk 1 to 6 & $2.64 \pm 0.36$ & $2.61 \pm 0.35$ & $2.66 \pm 0.37$ & $2.36 \pm 0.26$ & $2.91 \pm 0.32$ & 0.99 & $<0.01$ & 0.18 & 0.28 \\
\hline wk 2 & $2.92 \pm 0.37$ & $2.58 \pm 0.36$ & $2.59 \pm 0.38$ & & & & & & \\
\hline wk 4 & $2.31 \pm 0.42$ & $2.20 \pm 0.42$ & $2.58 \pm 0.43$ & & & & & & \\
\hline wk 6 & $1.52 \pm 0.45$ & $2.26 \pm 0.45$ & $2.15 \pm 0.46$ & & & & & & \\
\hline \multicolumn{10}{|l|}{ MUN, mg/dL } \\
\hline wk 1 to 6 & $12.7 \pm 0.3$ & $13.5 \pm 0.3$ & $13.4 \pm 0.4$ & $13.1 \pm 0.3$ & $13.3 \pm 0.3$ & 0.22 & 0.04 & 0.60 & 0.33 \\
\hline wk 2 & $11.7 \pm 0.5$ & $13.1 \pm 0.5$ & $13.9 \pm 0.5$ & & & & & & \\
\hline
\end{tabular}

${ }^{1}$ Treatments: $\mathrm{C}=$ controlled-energy prepartum diet, fed for ad libitum intake to control intake to $100 \%$ of energy requirements; I $=$ intermediateenergy prepartum diet, fed for ad libitum intake to control intake to $100 \%$ of energy requirements from 57 to $29 \mathrm{~d}$ before expected parturition and approximately $125 \%$ of energy requirements from $28 \mathrm{~d}$ before expected parturition until calving; $\mathrm{H}=$ high-energy prepartum diet, fed for ad libitum intake to achieve energy intake at approximately $150 \%$ of requirements.

${ }^{2}$ Fixed effects are treatment group $(\mathrm{T})$, parity $(\mathrm{P} ; 2$ or $\geq 3$ ), time, and 2-way interactions; interactions with $P \geq 0.05$ were excluded from the model except for treatment group $\times$ time.

${ }^{3}$ Linear score calculated $\left\{\log _{2}[(\mathrm{SCC} / 100,000)+3]\right\}$.

4, and 2 cows in group $\mathrm{C}, \mathrm{I}$, and $\mathrm{H}$ had retention of the placenta, respectively. Sample size was not sufficient to analyze differences in the number of health events.

\section{Parity Effect}

Compared with parity 2 animals, DMI of older animals was higher prepartum $(15.88 \pm 0.03$ vs. $14.73 \pm 0.2 \mathrm{~kg}$; $P=0.001)$, but energy balance postpartum tended to be lower (Table 4). Parity had an effect on postpartum BHBA and NEFA concentrations, with lower levels in parity 2 compared with parity $\geq 3$ (BHBA: $0.66 \pm 0.05$ vs. $0.81 \pm 0.06 \mathrm{mmol} / \mathrm{L}, P=0.03$; NEFA: $655 \pm 26$ vs. $757 \pm 32 \mu \mathrm{Eq} / \mathrm{L}, P=0.01$; Table 5 ). The percentage of milk fat was lower in parity 2 animals $(3.98 \pm 0.07$ vs. $4.24 \pm 0.08 \%, P=0.02)$, whereas the percent of lactose was higher in this parity group $(4.77 \pm 0.03$ vs. $4.67 \pm$ $0.03 \%, P=0.004$; Table 5).

\section{DISCUSSION}

Our primary objective in the current study was to investigate the effect of different prepartum feeding strategies differing in energy level on hyperketonemia. Our results show that animals overfed energy in the dry period had higher concentrations of both NEFA and BHBA postpartum, indicating a more severe negative energy balance in this group, as was also apparent 
Table 6. Milk FA yield (g/d) and concentrations (g/100g) of cows for wk 2 and 4 postpartum fed different dry period treatment diets

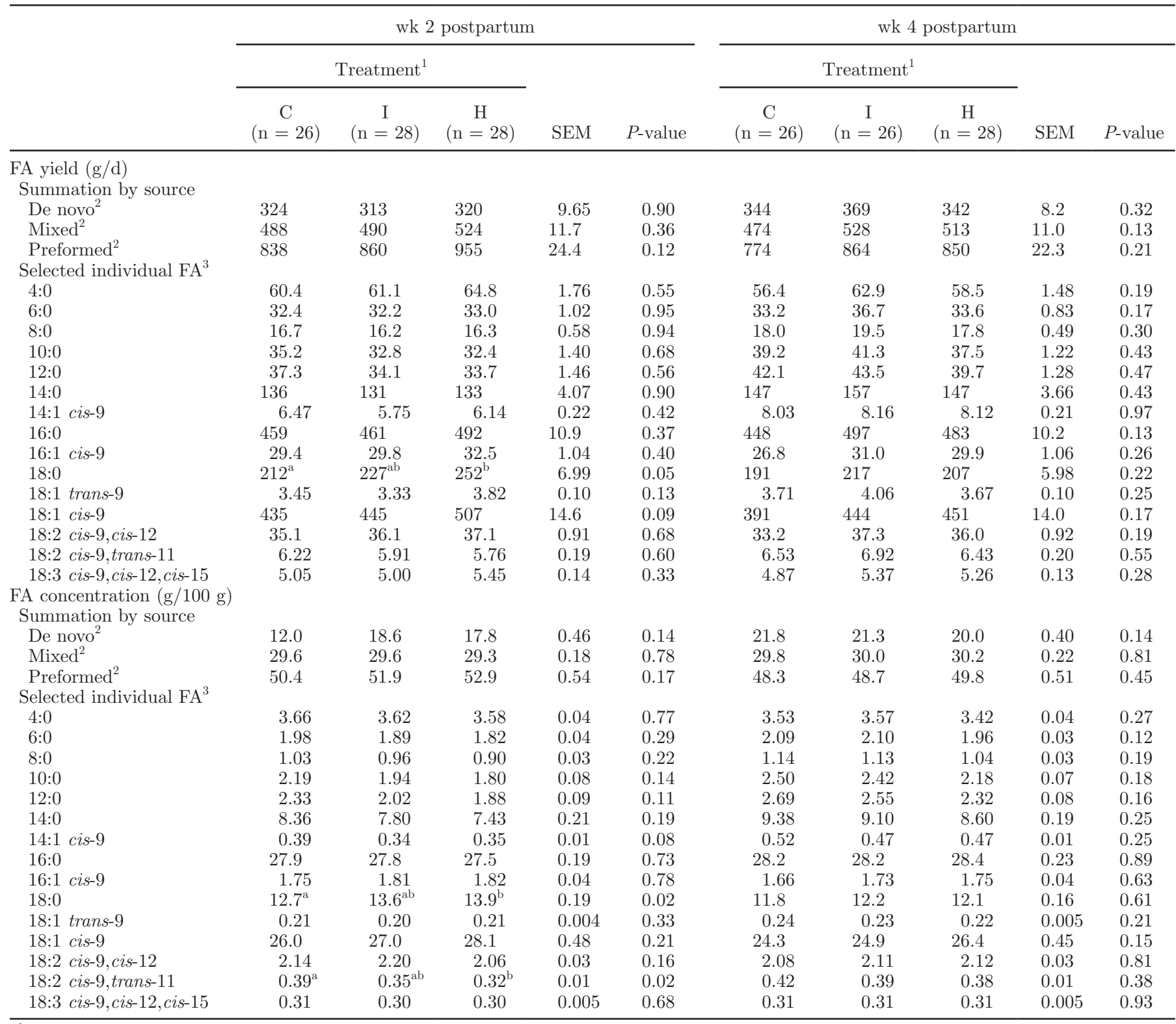

${ }^{\mathrm{a}, \mathrm{b}}$ Main effects of treatment in the same row with different superscripts differ $(P \leq 0.05)$.

${ }^{1}$ Treatments: $\mathrm{C}=$ controlled-energy prepartum diet, fed for ad libitum intake to control intake to $100 \%$ of energy requirements; $\mathrm{I}=$ intermediateenergy prepartum diet, fed for ad libitum intake to control intake to $100 \%$ of energy requirements from 57 to $29 \mathrm{~d}$ before expected parturition and approximately $125 \%$ of energy requirements from $28 \mathrm{~d}$ before expected parturition until calving; $\mathrm{H}=$ high-energy prepartum diet, fed for ad libitum intake to achieve energy intake at approximately $150 \%$ of requirements.

${ }^{2}$ De novo FA originate from de novo synthesis in the mammary gland ( $<16$ carbons), preformed FA originate from extraction from circulating plasma FA (>16 carbons), and mixed FA originate from both sources (C16:0 + cis-9 C16:1).

${ }^{3} \mathrm{~A}$ total of approximately 70 individual FA were quantified and used for calculations (summation by yield). Only select FA are reported.

in model estimates. These findings support the results reported by other investigators, concluding that it is advisable to prevent overfeeding energy in the dry period (Kunz et al., 1985; Dann et al., 2006; Janovick et al., 2011). Furthermore, data indicate that supplying an intermediate-energy diet during the close-up period alone can lead to at least some of the undesirable ef- fects that were related to overfeeding a higher-energy diet during the entire dry period. Our findings therefore support the application of a 1-group, controlled-energy dry cow program.

Higher NEFA concentrations were measured prepartum in the controlled-energy group. A higher concentration of NEFA in prepartum cows due to energy 

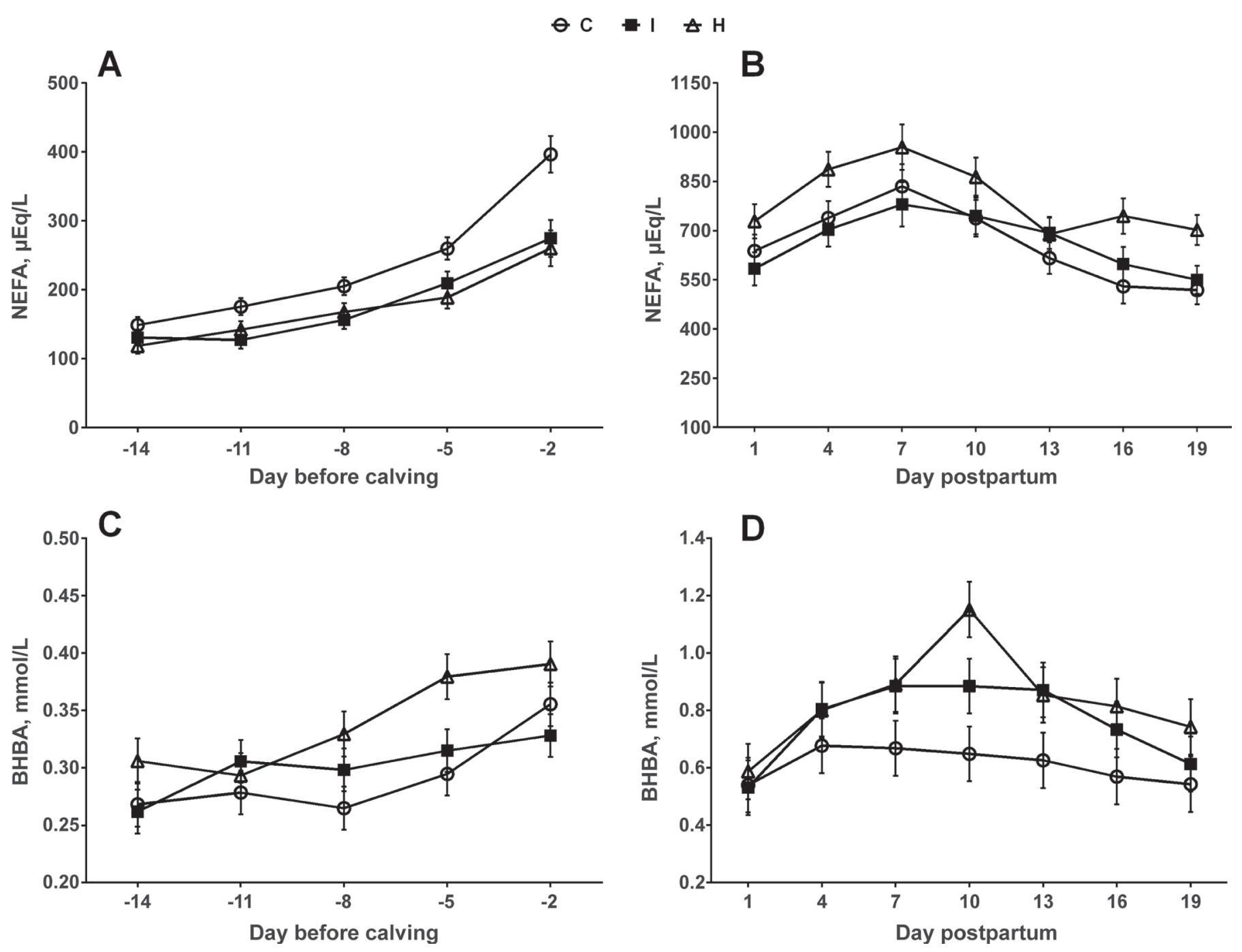

Figure 3. Concentration of metabolites in blood before morning feeding. Concentration of serum NEFA ( $\mu$ Eq/L; A) and BHBA (mmol/L; C) for the last $2 \mathrm{wk}$ before calving and for the first $3 \mathrm{wk}$ postpartum (B: NEFA, D: BHBA). C = controlled-energy prepartum diet, fed for ad libitum intake to control intake to $100 \%$ of energy requirements; I = intermediate-energy prepartum diet, fed for ad libitum intake to control intake to $100 \%$ of energy requirements from 57 to $29 \mathrm{~d}$ before expected parturition and approximately $125 \%$ of energy requirements from $28 \mathrm{~d}$ before expected parturition until calving; $\mathrm{H}=$ high-energy prepartum diet, fed for ad libitum intake to achieve energy intake at approximately $150 \%$ of requirements. At parturition, all cows were fed the same lactation diet. Data are presented as LSM \pm SE. BHBA prepartum: treatment, $P=0.04$; time, $P<0.001$; parity, $P=0.34$; treatment $\times$ time, $P=0.03$; time $\times$ parity, $P=0.04$. BHBA postpartum: treatment $P=0.04$; time, $P<0.001$; parity, $P=0.03$; treatment $\times$ time, $P=0.36$. NEFA prepartum: treatment, $P<0.001 ;$ time, $P<0.001 ;$ parity, $P=0.07$; treatment $\times$ time, $P=0.03$. NEFA postpartum: treatment, $P=0.02$; time, $P<0.001$; parity, $P=0.01$; treatment $\times$ time, $P=0.37$; treatment $\times$ parity, $P=0.004$. Parity was categorized into entering parity 2 or $\geq 3$. Interactions of main effects treatment, time, and parity removed if $P \geq 0.05$, except treatment $\times$ time, which was forced in the model.

restriction has been reported previously (Douglas et al., 2006; Janovick et al., 2011; Schoenberg and Overton, 2011). Possible reasons for this are a higher degree of negative energy balance immediately before parturition when DMI decreases (Radloff et al., 1966; Bell, 1995), or a smaller degree of insulin-mediated inhibition of lipolysis due to a lower insulin concentration in blood. Differences in DMI prepartum, which were likely attributable to a difference in rumen fill (Allen and Piantoni, 2013), did not carry over to the postpartum period.
As opposed to other studies (Douglas et al., 2006), we did not document an increase in DMI in the $\mathrm{C}$ group postpartum compared with the other treatment groups. The absence of an effect on early postpartum DMI after feeding a controlled- or restricted-energy diet supports descriptions by other researchers (Agenäs et al., 2003), although numerically higher intakes in prepartum energy-restricted groups were described (Holtenius et al., 2003; Dann et al., 2006). Regardless of a lack of difference in DMI postpartum, the different planes of 


\begin{tabular}{|c|c|c|c|c|c|c|c|c|c|c|c|}
\hline \multirow[b]{2}{*}{ Metabolite } & \multicolumn{3}{|c|}{ Treatment $^{1}( \pm \mathrm{SE})$} & \multicolumn{2}{|c|}{ Parity $( \pm \mathrm{SE})$} & \multicolumn{6}{|c|}{$P$-value for fixed effects ${ }^{2}$} \\
\hline & $\mathrm{C}$ & I & $\mathrm{H}$ & 2 & $\geq 3$ & $\mathrm{~T}$ & Time & $\mathrm{P}$ & $\mathrm{T} \times$ Time & $\mathrm{T} \times \mathrm{P}$ & Time $\times \mathrm{P}$ \\
\hline \multicolumn{4}{|l|}{ BHBA (mmol/L), prepartum } & $0.30 \pm 0.01$ & $0.32 \pm 0.01$ & 0.04 & $<0.001$ & 0.34 & 0.03 & & \\
\hline $\mathrm{d}-14$ & $0.27 \pm 0.02$ & $0.26 \pm 0.02$ & $0.31 \pm 0.02$ & $0.27 \pm 0.01$ & $0.28 \pm 0.02$ & & & & & & \\
\hline $\mathrm{d}-8$ & $0.27 \pm 0.02$ & $0.30 \pm 0.02$ & $0.33 \pm 0.02$ & $0.30 \pm 0.01$ & $0.30 \pm 0.02$ & & & & & & \\
\hline $\mathrm{d}-2$ & $0.36 \pm 0.02$ & $0.33 \pm 0.02$ & $0.39 \pm 0.02$ & $0.34 \pm 0.02$ & $0.38 \pm 0.02$ & & & & & & \\
\hline \multicolumn{12}{|l|}{ BHBA $(\mathrm{mmol} / \mathrm{L})$, postpartum } \\
\hline $\begin{array}{l}\text { d } 1 \text { to } 21 \\
\text { d } 1\end{array}$ & $\begin{array}{l}0.61 \pm 0.06^{\mathrm{a}} \\
0.54 \pm 0.10\end{array}$ & $\begin{array}{l}0.76 \pm 0.06^{\mathrm{ab}} \\
0.53 \pm 0.10\end{array}$ & $\begin{array}{l}0.84 \pm 0.07^{\circ} \\
0.58 \pm 0.10\end{array}$ & $0.66 \pm 0.05$ & $0.81 \pm 0.06$ & 0.04 & $<0.001$ & 0.03 & 0.36 & - & - \\
\hline d 7 & $0.67 \pm 0.10$ & $0.89 \pm 0.10$ & $0.89 \pm 0.10$ & & & & & & & & \\
\hline d 10 & $0.65 \pm 0.10$ & $0.89 \pm 0.10$ & $1.15 \pm 0.10$ & & & & & & & & \\
\hline d 13 & $0.63 \pm 0.10$ & $0.87 \pm 0.10$ & $0.85 \pm 0.10$ & & & & & & & & \\
\hline d 19 & $0.54 \pm 0.10$ & $0.61 \pm 0.10$ & $0.74 \pm 0.10$ & & & & & & & & \\
\hline \multicolumn{12}{|l|}{ NEFA $(\mu \mathrm{Eq} / \mathrm{L})$, prepartum } \\
\hline $\begin{array}{l}d-14 \text { to }-1 \\
d-14\end{array}$ & $149 \pm 11$ & $130 \pm 11$ & $\begin{array}{l}175 \pm 12 \\
118 \pm 11\end{array}$ & $186 \pm 9$ & $209 \pm 10$ & 0.001 & $<0.001$ & 0.07 & 0.03 & - & - \\
\hline $\mathrm{d}-8$ & $205 \pm 13$ & $156 \pm 13$ & $168 \pm 13$ & & & & & & & & \\
\hline $\mathrm{d}-2$ & $397 \pm 26$ & $275 \pm 27$ & $260 \pm 26$ & & & & & & & & \\
\hline \multicolumn{12}{|l|}{ NEFA $(\mu \mathrm{Eq} / \mathrm{L})$, postpartum } \\
\hline d 1 to 21 & $659 \pm 36^{\mathrm{a}}$ & $665 \pm 37^{\mathrm{a}}$ & $796 \pm 40^{b}$ & $655 \pm 26$ & $757 \pm 32$ & 0.02 & $<0.001$ & 0.01 & 0.37 & 0.004 & - \\
\hline d 1 & $638 \pm 50$ & $583 \pm 50$ & $729 \pm 52$ & & & & & & & & \\
\hline d 7 & $835 \pm 67$ & $780 \pm 67$ & $955 \pm 69$ & & & & & & & & \\
\hline d 10 & $734 \pm 56$ & $745 \pm 56$ & $864 \pm 58$ & & & & & & & & \\
\hline d 13 & $616 \pm 49$ & $693 \pm 49$ & $689 \pm 51$ & & & & & & & & \\
\hline d 19 & $518 \pm 43$ & $550 \pm 43$ & $702 \pm 46$ & & & & & & & & \\
\hline $\mathrm{C}$ & & & & $676 \pm 47$ & $643 \pm 50$ & & & & & & \\
\hline I & & & & $642 \pm 46$ & $687 \pm 52$ & & & & & & \\
\hline $\mathrm{H}$ & & & & $649 \pm 42$ & $943 \pm 63$ & & & & & & \\
\hline
\end{tabular}

7. Repeted measures ANOVA LSM for blood concentation of BHBA and serume concentration of NEFA

d -14 to -1 , prepartum

d-14

$\mathrm{d}-8$
$\mathrm{~d}-2$

BHBA (mmol/L), postpartum

d 7

d 13

d 19

NEFA $(\mu \mathrm{Eq} / \mathrm{L})$, prepartum

$$
\text { d-14 }
$$

$\mathrm{d}-2$

NEFA $(\mu \mathrm{Eq} / \mathrm{L})$, postpartum

d 1 to 21

$649 \pm 42 \quad 943 \pm 63$

${ }^{\mathrm{a}-\mathrm{c}}$ Main effects of treatment in the same row with different superscripts differ $(P \leq 0.05)$.

${ }^{1}$ Treatments: $\mathrm{C}=$ controlled-energy prepartum diet, fed for ad libitum intake to control intake to $100 \%$ of energy requirements; $\mathrm{I}=$ intermediate-energy prepartum diet, fed for ad libitum intake to control intake to $100 \%$ of energy requirements from 57 to 28 d before expected parturition and approximately $125 \%$ of energy requirements from $28 \mathrm{~d}$ before expected parturition until calving; $\mathrm{H}=$ high-energy prepartum diet, fed for ad libitum intake to achieve energy intake at approximately $150 \%$ of requirements.

${ }^{2}$ Fixed effects are treatment group $(\mathrm{T})$, parity $(\mathrm{P} ; 2$ or $\geq 3$ ), time, and 2-way interactions; interactions with $P \geq 0.05$ were excluded from the model except for treatment group $\times$ time. 
energy prepartum affected fat mobilization differently, as reflected by NEFA concentration as well as elevation in BHBA concentration. Dry matter intake decreased in all groups in the immediate prepartum period, as observed by others (Dann et al., 2006; Janovick et al., 2011; Vickers et al., 2013). Possible explanations are a rise in estrogen and other pregnancy-related factors, as reviewed in Grummer et al. (2004), as well as interactions between those and nutritional factors (Roche et al., 2013). Despite this drop in DMI prepartum, animals in the $\mathrm{C}$ group showed a less pronounced drop in feed intake relative to prior intakes compared with both the I and $\mathrm{H}$ group, maintaining DMI at a more constant level throughout the dry period. The change rather than the magnitude of DMI prepartum might have a greater effect on metabolic status of periparturient cows (Grummer et al., 2004).

In our study, monensin was included in all diets to more closely reflect feeding practices in modern dairy herds in the United States. Several authors have described the effect of monensin in the transition period (Petersson-Wolfe et al., 2007; Mullins et al., 2012), as well as in early lactating dairy cows (Duffield et al., 2008). According to those results, monensin was able to lead to a reduction in the blood concentration of BHBA postpartum both when given in the dry period as well as in early lactation. Therefore, it is possible that metabolic effects of the different treatments would have been more extreme in the absence of feeding monensin. Due to a lack of unsupplemented concurrent control groups, this remains speculation. Protein levels in the 3 treatment groups were formulated to ensure a margin of safety so that none of the cows would be protein deficient. As intakes were higher than predicted, predicted MP levels exceeded the formulated 1,280 g/d in all groups prepartum, but were similar across all groups.

Higher milk fat content in the $\mathrm{H}$ group was likely due to increased mobilization of fat depots in the first weeks of lactation (Palmquist et al., 1993). During this period, dietary supply of precursors for FA, such as acetate and glucose, are decreased and the mammary tissue synthesizes lower amounts of short-chain FA compared with a state of positive energy balance (Palmquist et al., 1993). Plasma NEFA can directly be taken up by the mammary gland, as is reflected by a positive correlation between plasma NEFA concentration and milk fat percent (Pullen et al., 1989). The differences in milk fat as well as the absence of a difference in milk protein among treatment groups explain the numerical differences in ECM, whereas treatment group did not affect milk production. Although fat mobilization can be due to various biological mechanisms and hormonal stimuli (Nielsen et al., 2014), we hypothesized that a higher degree of negative energy balance in the $\mathrm{H}$ group was associated with an increase in the rate of lipolysis as reflected by the higher concentration of NEFA (Rukkwamsuk et al., 1999). We found a higher concentration of the preformed FA C18:0 and cis-9 C18:1 in milk fat from cows being fed a higher-energy diet during the dry period, whereas the amount of de novo FA was similar among treatment groups. Differences in C18:0 between cows being fed different planes of energy during the dry period were also observed by Agenäs et al. (2003), and the authors hypothesized them to be due to a higher supply of FA from body origin. The FA cis$9 \mathrm{C} 18: 1$ is the desaturation product of C18:0 through the action of $\Delta(9)$-desaturase, and is the predominating FA in adipocytes (Nogalski et al., 2012). It is released during negative energy balance through lipolysis (Rukkwamsuk et al., 2000). The difference in the yield of cis-9 C18:1 inclusion in milk fat was present in both wk 2 and 4 postpartum, indicating that lipolysis and increased transfer of preformed FA persisted past the end of the transition period, typically considered as 21 DIM.

Animals in parity 2 had lower NEFA and BHBA concentrations postpartum compared with older animals. Higher odds of developing ketosis in cows at parity 3 and higher have previously been reported using serum (Duffield et al., 1997), a hand-held meter (McArt et al., 2013a; Suthar et al., 2013), or a milk-based test (Berge and Vertenten, 2014).

Although our intent was to best represent current feeding practices, there are limitations to our study that need to be considered. Cows on study were fed for ad libitum intake, but because of the housing system we could not account for possible effects of competition at the feed bunk as well as sorting behavior. These factors would need to be taken into account on most modern dairy farms with group housing and feeding. Moreover, because we set up a feeding model to also study glucose response and every cow received intravenous glucose at a dose of $0.25 \mathrm{~g} / \mathrm{kg}$ of BW twice during the dry and fresh period after completion of the morning blood sampling (data not presented), levels of NEFA and BHBA could have been altered at least in the short-term period and may have decreased the level of hyperketonemia in all groups. Because all cows received the same treatments, this potential effect would have equally altered responses in all groups; therefore, results for the degree of hyperketonemia observed are likely conservative.

When applying different diet formulation model systems [CNCPS and NRC (2001)], results differed both for energy density estimates of the diets as well as energy balance estimates. Regardless of the method chosen to estimate energy balance, the directional 
changes and magnitude of difference due to treatments were similar. However, the model systems yielded different estimates for the percentage of energy supplied. We believe that the difference can be attributed mostly to a difference in NDF digestibility used in the different model systems. To a smaller extent, differences could have been due to a disparity in the amount of energy requirements proposed for lactogenesis, supply of energy to the uterus and fetus in the dry period, as well as requirements for mammogenesis in the peripartum period. Drackley and Janovick Guretzky (2007) describe a similar discrepancy between different methods of energy density determination and recommend focusing on providing NDF and starch intake guidelines instead of energy density.

\section{CONCLUSIONS}

Results of this study showed an increased incidence of hyperketonemia in cows being fed a diet exceeding energy requirements during the whole dry period as well as in cows being fed a controlled-energy diet in the far-off period and then a moderate-energy diet in the close-up period. Milk production and postpartum DMI were not different among cows fed different planes of energy prepartum. Our findings support a 1-group, controlled-energy dry period feeding approach to minimize the degree of negative energy balance postpartum as well as hyperketonemia, possibly preventing negative health events shown to be correlated to an increase in BHBA concentration.

\section{ACKNOWLEDGMENTS}

This project is supported by the Agriculture and Food Research Initiative competitive grant no. 201267015-30230 from the USDA National Institute of Food and Agriculture (Washington, DC). The authors thank Mélissa Dupléssis (Université Laval, Quebec, Canada) and Rheanna Foley, Elizabeth Martens, Bryant Stuttle, and Tameeka Williams (Cornell University, Ithaca, NY) for their invaluable assistance with data collection. We acknowledge the technical assistance of Courtney Preseault and Carolina Ferreira (Michigan State University), for milk fatty acid analysis. We also thank the staff at the research dairy and Gladys Birdsall (Cornell Teaching and Research Center, Harford, NY).

\section{REFERENCES}

Agenäs, S., E. Burstedt, and K. Holtenius. 2003. Effects of feeding intensity during the dry period. 1. Feed intake, body weight, and milk production. J. Dairy Sci. 86:870-882. http://dx.doi. org/10.3168/jds.S0022-0302(03)73670-4.

Allen, M. S., and P. Piantoni. 2013. Metabolic control of feed intake: Implications for metabolic disease of fresh cows. Vet. Clin. North Am. Food Anim. Pract. 29:279-297. http://dx.doi.org/10.1016/j. cvfa.2013.04.001.

AOAC International. 2012. Official Methods of Analysis. 19th ed. AOAC International, Arlington, VA

Bell, A. W. 1995. Regulation of organic nutrient metabolism during transition from late pregnancy to early lactation. J. Anim. Sci. 73:2804-2819.

Berge, A. C., and G. Vertenten. 2014. A field study to determine the prevalence, dairy herd management systems, and fresh cow clinical conditions associated with ketosis in western European dairy herds. J. Dairy Sci. 97:2145-2154. http://dx.doi.org/10.3168/ jds.2013-7163.

Busato, A., D. Faissle, U. Kupfer, and J. W. Blum. 2002. Body condition scores in dairy cows: Associations with metabolic and endocrine changes in healthy dairy cows. J. Vet. Med. A Physiol. Pathol. Clin. Med. 49:455-460.

Dairy One Cooperative. 2014. Analytical Procedures-Forage, Manure, Water. Accessed Sep. 14, 2014. http://dairyone.com/wpcontent/uploads/2014/02/Forage-Lab-Analytical-Procedures.pdf.

Dann, H. M., N. B. Litherland, J. P. Underwood, M. Bionaz, A D'Angelo, J. W. McFadden, and J. K. Drackley. 2006. Diets during far-off and close-up dry periods affect periparturient metabolism and lactation in multiparous cows. J. Dairy Sci. 89:3563-3577. http://dx.doi.org/10.3168/jds.S0022-0302(06)72396-7.

Dann, H. M., D. E. Morin, G. A. Bollero, M. R. Murphy, and J. K. Drackley. 2005. Prepartum intake, postpartum induction of ketosis, and periparturient disorders affect the metabolic status of dairy cows. J. Dairy Sci. 88:3249-3264. http://dx.doi.org/10.3168/jds. S0022-0302(05)73008-3.

Douglas, G. N., T. R. Overton, H. G. Bateman 2nd, H. M. Dann, and J. K. Drackley. 2006. Prepartal plane of nutrition, regardless of dietary energy source, affects periparturient metabolism and dry matter intake in Holstein cows. J. Dairy Sci. 89:2141-2157. http://dx.doi.org/10.3168/jds.S0022-0302(06)72285-8.

Drackley, J. K. 1999. ADSA Foundation Scholar Award. Biology of dairy cows during the transition period: the final frontier? J. Dairy Sci. 82:2259-2273.

Drackley, J. K., and N. A. Janovick Guretzky. 2007. Controlled energy diets for dry cows. Pages 7-16 in Proc. Western Dairy Management Conference, Reno, NV.

Drehmann, P. C. 2000. Should we rethink our close-up rations? Hoard's Dairyman 145:641

Duffield, T. F., D. F. Kelton, K. E. Leslie, K. D. Lissemore, and J H. Lumsden. 1997. Use of test day milk fat and milk protein to detect subclinical ketosis in dairy cattle in Ontario. Can. Vet. J. 38:713-718.

Duffield, T. F., K. D. Lissemore, B. W. McBride, and K. E. Leslie. 2009. Impact of hyperketonemia in early lactation dairy cows on health and production. J. Dairy Sci. 92:571-580. http://dx.doi. org $/ 10.3168 /$ jds. $2008-1507$.

Duffield, T. F., A. R. Rabiee, and I. J. Lean. 2008. A meta-analysis of the impact of monensin in lactating dairy cattle. Part 1. Metabolic effects. J. Dairy Sci. 91:1334-1346. http://dx.doi.org/10.3168/ jds.2007-0607.

Edmonson, A. J., I. J. Lean, L. D. Weaver, T. Farver, and G. Webster. 1989. A body condition scoring chart for Holstein dairy cows J. Dairy Sci. 72:68-78. http://dx.doi.org/10.3168/jds.S00220302(89)79081-0.

Goff, J. P., and R. L. Horst. 1997. Physiological changes at parturition and their relationship to metabolic disorders. J. Dairy Sci. 80:12601268. http://dx.doi.org/10.3168/jds.S0022-0302(97)76055-7.

Grum, D. E., J. K. Drackley, R. S. Younker, D. W. LaCount, and J. J. Veenhuizen. 1996. Nutrition during the dry period and hepatic lipid metabolism of periparturient dairy cows. J. Dairy Sci. 79:18501864. http://dx.doi.org/10.3168/jds.S0022-0302(96)76553-0. 
Grummer, R. R. 1995. Impact of changes in organic nutrient metabolism on feeding the transition dairy cow. J. Anim. Sci. 73:28202833.

Grummer, R. R., D. G. Mashek, and A. Hayirli. 2004. Dry matter intake and energy balance in the transition period. Vet. Clin. North Am. Food Anim. Pract. 20:447-470. http://dx.doi.org/10.1016/j. cvfa.2004.06.013.

Hammon, D. S., I. M. Evjen, T. R. Dhiman, J. P. Goff, and J. L. Walters. 2006. Neutrophil function and energy status in Holstein cows with uterine health disorders. Vet. Immunol. Immunopathol. 113:21-29. http://dx.doi.org/10.1016/j.vetimm.2006.03.022.

Holtenius, K., S. Agenas, C. Delavaud, and Y. Chilliard. 2003. Effects of feeding intensity during the dry period. 2. Metabolic and hormonal responses. J. Dairy Sci. 86:883-891. http://dx.doi. org/10.3168/jds.S0022-0302(03)73671-6.

Holter, J. B., M. J. Slotnick, H. H. Hayes, C. K. Bozak, W. E. Urban Jr., and M. L. McGilliard. 1990. Effect of prepartum dietary energy on condition score, postpartum energy, nitrogen partitions, and lactation production responses. J. Dairy Sci. 73:3502-3511. http://dx.doi.org/10.3168/jds.S0022-0302(90)79050-9.

Iwersen, M., U. Falkenberg, R. Voigtsberger, D. Forderung, and W. Heuwieser. 2009. Evaluation of an electronic cowside test to detect subclinical ketosis in dairy cows. J. Dairy Sci. 92:2618-2624. http://dx.doi.org/10.3168/jds.2008-1795.

Janovick, N. A., Y. R. Boisclair, and J. K. Drackley. 2011. Prepartum dietary energy intake affects metabolism and health during the periparturient period in primiparous and multiparous Holstein cows. J. Dairy Sci. 94:1385-1400. http://dx.doi.org/10.3168/jds.20103303.

Janovick, N. A., and J. K. Drackley. 2010. Prepartum dietary management of energy intake affects postpartum intake and lactation performance by primiparous and multiparous Holstein cows. J. Dairy Sci. 93:3086-3102. http://dx.doi.org/10.3168/jds.2009-2656.

Kunz, P. L., J. W. Blum, I. C. Hart, H. Bickel, and J. Landis. 1985. Effects of different energy intakes before and after calving on food intake, performance and blood hormones and metabolites in dairy cows. Anim. Prod. 40:219-231. http://dx.doi.org/10.1017/ S0003356100025320.

Lock, A. L., C. L. Preseault, J. E. Rico, K. E. DeLand, and M. S. Allen. 2013. Feeding a C16:0-enriched fat supplement increased the yield of milk fat and improved conversion of feed to milk. J. Dairy Sci. 96:6650-6659. http://dx.doi.org/10.3168/jds.2013-6892.

Mashek, D. G., and D. K. Beede. 2001. Peripartum responses of dairy cows fed energy-dense diets for 3 or 6 weeks prepartum. J. Dairy Sci. 84:115-125. http://dx.doi.org/10.3168/jds.S00220302(01)74459-1.

McArt, J. A., D. V. Nydam, and G. R. Oetzel. 2012. A field trial on the effect of propylene glycol on displaced abomasum, removal from herd, and reproduction in fresh cows diagnosed with subclinical ketosis. J. Dairy Sci. 95:2505-2512. http://dx.doi.org/10.3168/ jds.2011-4908.

McArt, J. A., D. V. Nydam, and G. R. Oetzel. 2013a. Dry period and parturient predictors of early lactation hyperketonemia in dairy cattle. J. Dairy Sci. 96:198-209. http://dx.doi.org/10.3168/ jds.2012-5681.

McArt, J. A., D. V. Nydam, G. R. Oetzel, T. R. Overton, and P. A. Ospina. 2013b. Elevated non-esterified fatty acids and betahydroxybutyrate and their association with transition dairy cow performance. Vet. J. 198:560-570. http://dx.doi.org/10.1016/j. tvjl.2013.08.011.

McNamara, S., F. P. O’Mara, M. Rath, and J. J. Murphy. 2003. Effects of different transition diets on dry matter intake, milk production, and milk composition in dairy cows. J. Dairy Sci. 86:2397-2408. http://dx.doi.org/10.3168/jds.S0022-0302(03)73834-X.

Minor, D. J., S. L. Trower, B. D. Strang, R. D. Shaver, and R. R. Grummer. 1998. Effects of nonfiber carbohydrate and niacin on periparturient metabolic status and lactation of dairy cows. J. Dairy Sci. 81:189-200. http://dx.doi.org/10.3168/jds.S00220302(98)75566-3.
Mullins, C. R., L. K. Mamedova, M. J. Brouk, C. E. Moore, H. B. Green, K. L. Perfield, J. F. Smith, J. P. Harner, and B. J. Bradford. 2012. Effects of monensin on metabolic parameters, feeding behavior, and productivity of transition dairy cows. J. Dairy Sci. 95:1323-1336. http://dx.doi.org/10.3168/jds.2011-4744.

Nielsen, T. S., N. Jessen, J. O. Jorgensen, N. Moller, and S. Lund. 2014. Dissecting adipose tissue lipolysis: Molecular regulation and implications for metabolic disease. J. Mol. Endocrinol. 52:R199R222. http://dx.doi.org/10.1530/JME-13-0277.

Nogalski, Z., M. Wronski, M. Sobczuk-Szul, M. Mochol, and P. Pogorzelska. 2012. The effect of body energy reserve mobilization on the fatty acid profile of milk in high-yielding cows. Asian-australas. J. Anim. Sci. 25:1712-1720. http://dx.doi.org/10.5713/ ajas.2012.12279.

NRC. 2001. Nutrient Requirements of Dairy Cattle. 7th rev. ed. Natl. Acad. Press, Washington, DC.

NRC. 2012. Nutrient Requirements of Dairy Cattle Downloadable Model v.1.1.9 December 2012, 7th rev. ed. Natl. Acad. Press, Washington, DC. Accessed Jun. 3, 2014. http://www.nap.edu/ catalog/dairymodel/.

Olsson, G., M. Emanuelson, and H. Wiktorsson. 1998. Effects of different nutritional levels prepartum on the subsequent performance of dairy cows. Livest. Prod. Sci. 53:279-290. http://dx.doi. org/10.1016/S0301-6226(97)00022-5

Ospina, P. A., D. V. Nydam, T. Stokol, and T. R. Overton. 2010a. Evaluation of nonesterified fatty acids and beta-hydroxybutyrate in transition dairy cattle in the northeastern United States: Critical thresholds for prediction of clinical diseases. J. Dairy Sci. 93:546-554. http://dx.doi.org/10.3168/jds.2009-2277.

Ospina, P. A., D. V. Nydam, T. Stokol, and T. R. Overton. 2010b. Associations of elevated nonesterified fatty acids and beta-hydroxybutyrate concentrations with early lactation reproductive performance and milk production in transition dairy cattle in the northeastern United States. J. Dairy Sci. 93:1596-1603. http:// dx.doi.org/10.3168/jds.2009-2852.

Ospina, P. A., D. V. Nydam, T. Stokol, and T. R. Overton. 2010c. Association between the proportion of sampled transition cows with increased nonesterified fatty acids and beta-hydroxybutyrate and disease incidence, pregnancy rate, and milk production at the herd level. J. Dairy Sci. 93:3595-3601. http://dx.doi.org/10.3168/ jds.2010-3074.

Palmquist, D. L., A. D. Beaulieu, and D. M. Barbano. 1993. Feed and animal factors influencing milk fat composition. J. Dairy Sci. $76: 1753-1771$.

Petersson-Wolfe, C. S. K. E. Leslie, T. Osborne, B. W. McBride, R. Bagg, G. Vessie, P. Dick, and T. F. Duffield. 2007. Effect of monensin delivery method on dry matter intake, body condition score, and metabolic parameters in transition dairy cows. J. Dairy Sci. 90:1870-1879. http://dx.doi.org/10.3168/jds.2006-402

Piantoni, P., A. L. Lock, and M. S. Allen. 2013. Palmitic acid increased yields of milk and milk fat and nutrient digestibility across production level of lactating cows. J. Dairy Sci. 96:7143-7154. http://dx.doi.org/10.3168/jds.2013-6680.

Pullen, D. L., D. L. Palmquist, and R. S. Emery. 1989. Effect on days of lactation and methionine hydroxy analog on incorporation of plasma fatty acids into plasma triglycerides. J. Dairy Sci. 72:4958. http://dx.doi.org/10.3168/jds.S0022-0302(89)79079-2.

Rabelo, E., R. L. Rezende, S. J. Bertics, and R. R. Grummer. 2003. Effects of transition diets varying in dietary energy density on lactation performance and ruminal parameters of dairy cows. J. Dairy Sci. 86:916-925. http://dx.doi.org/10.3168/jds.S00220302(03)73674-1.

Radloff, H. D., L. H. Schultz, and W. G. Hoekstra. 1966. Relationship of plasma free fatty acids to other blood components in ruminants under various physiological conditions. J. Dairy Sci. 49:179-182. http://dx.doi.org/10.3168/jds.S0022-0302(66)87821-9.

Roche, J. R., A. W. Bell, T. R. Overton, and J. J. Loor. 2013. Nutritional management of the transition cow in the 21st centuryA paradigm shift in thinking. Anim. Prod. Sci. 53:1000-1023. http://dx.doi.org/10.1071/AN12293. 
Rukkwamsuk, T., M. J. Geelen, T. A. Kruip, and T. Wensing. 2000. Interrelation of fatty acid composition in adipose tissue, serum, and liver of dairy cows during the development of fatty liver postpartum. J. Dairy Sci. 83:52-59. http://dx.doi.org/10.3168/jds. S0022-0302(00)74854-5.

Rukkwamsuk, T., T. A. Kruip, and T. Wensing. 1999. Relationship between overfeeding and overconditioning in the dry period and the problems of high producing dairy cows during the postparturient period. Vet. Q. 21:71-77. http://dx.doi.org/10.1080/016521 76.1999.9694997.

Schoenberg, K. M., and T. R. Overton. 2011. Effects of plane of nutrition and 2,4-thiazolidinedione on insulin responses and adipose tissue gene expression in dairy cattle during late gestation. J. Dairy Sci. 94:6021-6035. http://dx.doi.org/10.3168/jds.2011-4533.

Sirois, P. K., M. J. Reuter, C. M. Laughlin, and P. J. Lockwood. 1994 A method for determining macro and micro elements in forages and feeds by inductively coupled plasma atomic emission spectrometry. Spectroscopist 3:6-9.

Suthar, V. S., J. Canelas-Raposo, A. Deniz, and W. Heuwieser. 2013. Prevalence of subclinical ketosis and relationships with postpartum diseases in European dairy cows. J. Dairy Sci. 96:2925-2938. http://dx.doi.org/10.3168/jds.2012-6035.

Urbaniak, G. C. Plous. S. 2012. Research Randomizer. Ver. 4.0. Accessed Aug. 12, 2012. http://www.randomizer.org/form.htm.

Van Soest, P. J., J. B. Robertson, and B. A. Lewis. 1991. Methods for dietary fiber, neutral detergent fiber, and nonstarch polysaccharides in relation to animal nutrition. J. Dairy Sci. 74:3583-3597. http://dx.doi.org/10.3168/jds.S0022-0302(91)78551-2.

Vickers, L. A., D. M. Weary, D. M. Veira, and M. A. von Keyserlingk. 2013. Feeding a higher forage diet prepartum decreases incidences of subclinical ketosis in transition dairy cows. J. Anim. Sci. 91:886-894. http://dx.doi.org/10.2527/jas.2011-4349. 